\title{
Polychromatism of populations of Corallus hortulanus (Squamata: Boidae) from the southern Amazon Basin, Brazil
}

\author{
Mel de Oliveira DUARTE ${ }^{1 *}$, Tiago Magalhães da Silva FREITAS², Ana Lúcia da Costa PRUDENTE \\ 1 Universidade Federal do Pará / Museu Paraense Emílio Goeldi, Pós-Graduação em Zoologia. Avenida Perimetral, 1901, caixa postal 399, CEP 66017-970, bairro da Terra Firme, \\ Belém, PA, Brasil. \\ 2 Universidade Federal do Pará, Campus Universitário do Marajó, Faculdade de Ciências Naturais. Conjunto Bandeirante, bairro Aeroporto, $68800-000$ Breves, PA, Brasil. \\ ${ }^{3}$ Museu Paraense Emílio Goeldi, Departamento de Zoologia, Laboratório de Herpetologia. Avenida Perimetral, 1901, caixa postal 399, CEP 66017-970, bairro da Terra Firme, Belém, \\ PA, Brasil. \\ * Corresponding author: meldeoliveiraduarte@gmail.com
}

\begin{abstract}
The Amazon tree boa Corallus hortulanus is known for featuring a wide variation in color pattern and design markings. Although there are studies on its polychromatism, none of them addresses the geographic variation in the color pattern of this species. The aim of this study was to describe the chromatic variation found in the populations of $C$. hortulanus from the southern Amazon Basin and its relationship with geographic distribution of the species. Analysis of both design markings and color patterns on 112 C. hortulanus specimens from the southern Amazon Basin interfluves resulted in the identification of six distinct morphotypes. Grayish-brown coloration and elongated diamond-shaped patterns were the most frequent patterns. Two morphotypes showed a tendency of correlation with the geographical distribution of those species found in Madeira and Juruá Rivers. The small sample size does not allow for a robust conclusion on the possible cause of geographic variation. The distribution of morphological patterns of $C$. hortullanus in the Amazon Basin suggest that there is gene flow between populations, regardless of geographical distance and natural barriers. The variation in color pattern and markings may represent a phenotypic response to the characteristics of different habitats occupied by the species.
\end{abstract}

KEYWORDS: color patterns, snake, Amazonia.

\section{Policromatismo das populações de Corallus hortulanus (Squamata: Boidae) ao sul da Bacia Amazônica, Brasil}

RESUMO

Corallus hortulanus é uma serpente conhecida por apresentar grande variação no padrão de coloração e desenho. Apesar de estudos relacionados ao seu policromatismo, nenhum deles abordou a variaçáo geográfica no padrão de cor desta espécie. $\mathrm{O}$ objetivo deste estudo foi descrever a variação cromática das populaçóes de C. hortulanus na Calha sul do Rio Amazonas e verificar a correlação entre a distribuição geográfica e a variação encontrada. A partir da análise do padrão de desenho e cor de 112 espécimes de $C$. hortulanus procedentes dos interflúvios (área entre dois rios) da Calha Sul foram descritos seis morfotipos. Dos seis morfotipos descritos, a cor marrom-acinzentado e o padrão de desenho losango alongado foram os mais comuns entre as populações analisadas. Dois morfotipos apresentaram uma tendência de correlação com a distribuição geográfica, estando relacionados aos rios Madeira e Juruá, embora o número de amostras tenha sido pequeno. A distribuição dos padrōes morfológicos de C. hortullanus na Bacia Amazônica revelou que existe fluxo gênico entre as populaçóes, independentemente da distância geográfica e das barreiras naturais. Provavelmente, o padrão de cor e desenho seja uma resposta fenotípica às pressóes nos diferentes ambientes ocupados pela espécie.

PALAVRAS-CHAVE: padróes cromáticos, serpente, Amazônia. 


\section{INTRODUCTION}

Corallus is a Boidae genus with nine nominal species: $C$. batesii (Gray, 1860), C. blombergi (Rendahl and Vestergren, 1941), C. cookii (Gray, 1842), C. grenadensis (Barbour, 1914), C. ruschenbergerii (Cope, 1876), C. annulatus (Cope, 1876), C. caninus (Linnaeus, 1758), C. cropanii (Hoge, 1954) and $C$. hortulanus (Linnaeus, 1758) (Henderson 1997). They occur from northern Central America to southeast Brazil, south of Tropic of Capricorn, oceanic islands - Sao Vicente and Banco de Granada - and continental islands of Panama, Brazil and Venezuela (Henderson 1997). Corallus hortulanus, C. caninus and $C$. batesii are widely present in the Amazon region while the other species have restricted and peripheral distribution (Henderson 1997). Among its congeners, C. hortulanus is the species with the widest geographical distribution (Cunha and Nascimento 1993; Noonan and Chippindale 2006). It can be found in the tropical rainforests of Brazil, Guyanas, southeast Colombia, southeast Venezuela, Ecuador, Peru, Bolivia, as well as in Brazilian open areas such as Cerrado and Caatinga (Henderson et al. 1995; Rodrigues 1996; Henderson 1997).

The most conspicuous feature of $C$. hortulanus is the large chromatic variation of individuals with sharp ontogenetic dimorphism (Cunha and Nascimento 1993; Henderson 1997), which may lead to some taxonomic conflicts. The species may have individuals of the same nest with color patterns and distinct design (Freitas 2003). Such phenotypic variation can be explained by a set of environmental factors, which may influence its behavior and gene flow rate among populations (Henderson 1997). According to some studies, its polymorphism may be linked to different variables such as behavior, thermoregulation, metabolism, interactions with environment, predator-prey interactions through mimicry, aposematism and camouflage, and higher occupancy of habitat; besides indicating resilience/ age of the species (Terribile et al. 2009; Farallo and Forstner 2012; Pizzatto and Dubey 2012).

The aim of this study was to describe the chromatic variation found in the populations of $C$. hortulanus from the southern Amazon Basin (right bank of Amazon River), and also record how this variation is distributed through the main interfluves (area between two rivers) as well as verify the sexual proportion of the described morphotypes.

\section{MATERIALS AND METHODS}

For the morphological analysis, herpetological collections in Museu Paraense Emílio Goeldi (MPEG, Pará, Brazil), Museu de Zoologia da Universidade de São Paulo (MZUSP, São Paulo, Brazil) and Instituto de Biologia da Universidade de São Paulo (IB-USP, São Paulo, Brazil) were consulted. The analyzed species (112 in total) were previously defined in groups according to origin, considering the main tributaries to the south of Amazon River or Basin (Tocantins, Xingu,
Tapajós, Madeira, Purus and Juruá Rivers), consisting of seven populations, namely: East of Tocantins (30), Tocantins/Xingu (32), Xingu/Tapajós (6), Tapajós/Madeira (25), Madeira/Purus (8), Purus/Juruá (8), and West of Juruá (3). For comparative purposes and complementing data, other populations of species C. hortulanus were also used: North Amazon Basin (left bank tributaries of Solimóes/Amazonas Rivers, 13) and other biomes (Cerrado, Caatinga and Atlantica forest; 13).

The morphotypes were redefined based on the proposal of Henderson (1997), analyzing the dorsal, lateral and ventral regions of the head, body and tail, considering the main element and the secondary spots. Three categories for the dorsal design pattern were defined: spotless, with small circular spots and elongated diamond-shaped spots. At the same time, the background colors and spots were classified into eight categories: brown; beige, including various shades of yellowish-brown and light brown; grayish-brown; gray; cream, which includes light yellow tones; yellow; orange; and white. Numbering in brackets, under the shade guide of Smith (1975), was used for color illustration. Considering the fact that the color of animals is lost or disappears in individuals preserved in alcohol (Henderson 1997), specimens, which had a very old collection date (below the year of 1969) and had faded in color (body without spots or too light-colored), were disregarded from the analysis.

To verify the occurrence of possible dimorphism patterns between the sexes and within the different morphotypes, the sex ratio was calculated with use of Chi-Square $\left(X^{2}\right)$, testing as a null hypothesis that the sex ratio is independent of the morphotype. The analysis was carried out by the "Paleontological Statistics Software Package for Education and Data Analysis" (PAST version 1.82b; Hammer et al. 2001), using a 5\% significance level. Specimens from both banks of the Amazon River were considered for this analysis. Considering ontogenetic dimorphism (Henderson 1997), specimens sexually immature were disregarded from the morphological analysis considering that sexual maturity occurs in individuals with snout-vent length (SVL) equal to or greater than $802 \mathrm{~mm}$ (Pizzato and Marques 2007).

All samples were georeferenced and for specimens without coordinate records we used the coordinates of the geographic center of the city where they were collected.

\section{RESULTS}

Based on designs and color patterns, it was possible to define six morphotypes in populations of $C$. hortulanus from the south basin of Amazon River (Table 1). The populations with the greatest number of morphotypes were: East of Tocantins, Tocantins/Xingu and Tapajós/Madeira, each with five different morphotypes; while the West of Juruá population had the lowest number of morphotypes. 
Table 1. Distribution of morphotypes (M) of Corallus hortulanus present in interfluves in the South of Amazon River, Brazil. Absent numbers are indicated with (-).

\begin{tabular}{|c|c|c|c|c|c|c|c|c|c|c|c|c|c|}
\hline \multirow{3}{*}{ Interfluves } & \multicolumn{13}{|c|}{ Morphotypes (M) } \\
\hline & \multicolumn{2}{|c|}{ M1 } & \multicolumn{2}{|c|}{ M2 } & \multicolumn{2}{|c|}{ M3 } & \multicolumn{2}{|c|}{ M4 } & \multicolumn{2}{|c|}{ M5 } & \multicolumn{2}{|c|}{ M6 } & \multirow{2}{*}{ TOTAL } \\
\hline & $\mathrm{N}$ & $\%$ & $\mathrm{~N}$ & $\%$ & $\mathrm{~N}$ & $\%$ & $\mathrm{~N}$ & $\%$ & $\mathrm{~N}$ & $\%$ & $\mathrm{~N}$ & $\%$ & \\
\hline East of Tocantins & 4 & 44.4 & 1 & 14.3 & 3 & 13.0 & 16 & 48.5 & 6 & 11.8 & - & - & 30 \\
\hline Tocantins/Xingu & 1 & 11.1 & 2 & 28.6 & 10 & 43.5 & - & - & 18 & 35.3 & 1 & 50.0 & 32 \\
\hline Xingu/Tapajós & - & - & 1 & 14.3 & 1 & 4.3 & - & - & 4 & 7.8 & - & - & 6 \\
\hline Tapajós/Madeira & 3 & 33.3 & 3 & 42.9 & 3 & 13.0 & 5 & 15.2 & 11 & 21.6 & - & - & 25 \\
\hline Madeira/Purus & - & - & - & - & 1 & 4.3 & - & - & 6 & 11.8 & 1 & 50.0 & 8 \\
\hline Purus/Juruá & - & - & - & - & 1 & 4.3 & 4 & 12.1 & 3 & 5.9 & - & - & 8 \\
\hline West of Juruá & - & - & - & - & - & - & 1 & 3.0 & 2 & 3.9 & - & - & 3 \\
\hline North Basin & 1 & 11.1 & - & - & 4 & 17.4 & 7 & 21.2 & 1 & 2.0 & - & - & 13 \\
\hline TOTAL & 9 & 7.2 & 7 & 5.6 & 23 & 18.4 & 33 & 26.4 & 51 & 40.8 & 2 & 100.0 & 125 \\
\hline
\end{tabular}

\section{Description of morphological patterns}

Morphotype 1 (nine specimens) - specimens with lightcolored body, in shades of beige and cream and dark spots in shades of brown, well outlined and marked, forming geometric patterns of elongated diamonds (Figure 1).

Description: Head-light background color, shades of cream (54, 92 and/or 124) and beige (24), with dark spots, shades of brown (22, 23 and/or 223A). The posterior region of the head had three dark, longitudinal and parallel spots, with two lateral and one central spot. At the rear end, perpendicularly arranged, two small spots were present, which could be circular or linear. Between the eyes, there were small, irregularly arranged spots, which could be joined. Postorbital stripe distinguished from the background. Some specimens had dark, large and ill-outlined spots, prevailing on the background, being more concentrated in the snout region; lighter-colored infralabial, with few dark spots; and the postorbital stripe was lighter and less evident. Ventral region of the head had lighter shades of cream (54) than the dorsal region. Body: light-colored background in shades of cream (54, 92, 118 and/or 124; Figure 1), with dark spots, shades of brown (22, 23 and/or $223 \mathrm{~A}$ ), more evident on the dorsal region, which could extend to the abdomen. These spots were the result of the union of many small spots that tended to form geometric patterns of elongated diamonds. Such markings varied among individuals on dorsal-ventral direction, and they could be incomplete, in the shape of triangles. Possible presence of secondary linear spots arranged between the diamond-shaped ones. Abdomen was lighter-colored than dorsum (cream, 54) and spotless (Figure 1). In some individuals we perceived that the joining of small spots did not result in defined geometric patterns. In such cases, it was common for the individuals to show small, circular spots on the sides of belly. Those that ornamented the body with diamond-shaped, well-defined spots tended to have the same pattern of markings on the head and tail. Tail: background color the same as body (shades of cream; 54, 92, 118 and/or 124) and dark dorsal spots (shades of brown; 22, 23 and/or 223A) which were also the result of small spots that joined together forming small diamonds, empty or not. It was observed in several individuals some secondary small spots, which interposed with the bigger ones. The diamonds extended to the belly, which was light-colored (cream; 54; Figure 1). In some individuals the diamonds were not well-defined.

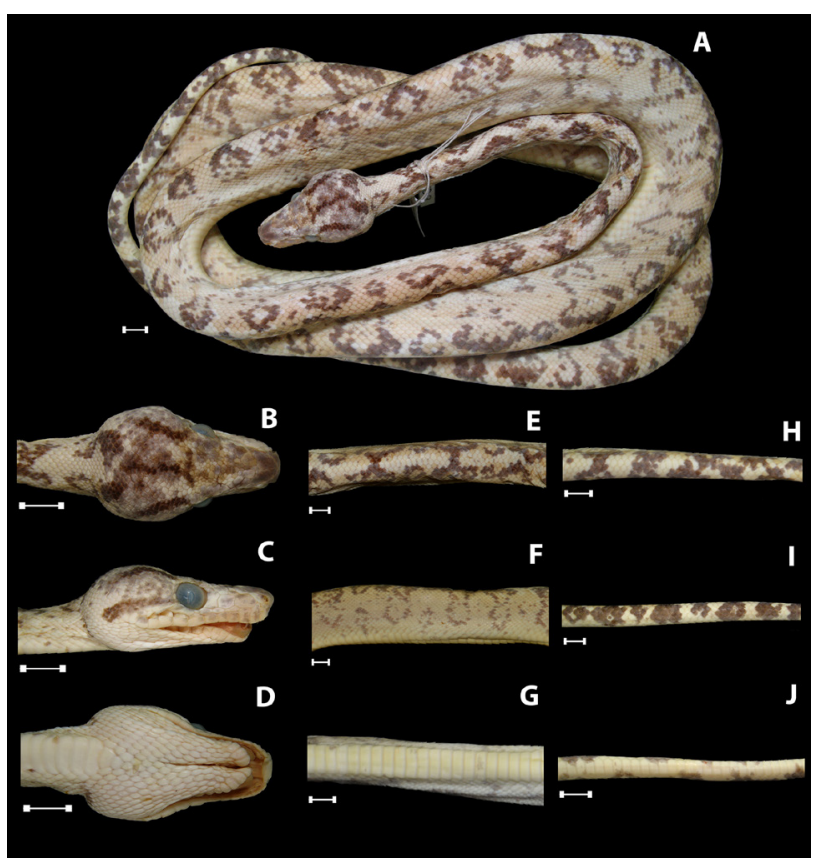

Figure 1. Morphotype 1 of Corallus hortulanus representing overview body $(A)$; cephalic region in dorsal $(B)$, lateral $(C)$, and ventral view $(C)$; median region of the body in dorsal $(E)$, lateral $(F)$, and ventral view $(G)$; dorsal $(M)$, lateral (I), and ventral view of caudal region (J). Scale bar $=10 \mathrm{~mm}$. Image colored in the electronic version. 
Distribution: Present in three interfluves of the South of Amazon River: East of Tocantins (4), Tocantins/Xingu (1) and Tapajós/Madeira (3) as well as in the North of the Amazon River (1).

Morphotype 2 (seven specimens) - specimens with lightcolored body, shades of orange, cream and beige with many small, circular dark spots distributed randomly throughout the body.

Description: Head - dark background, shades of beige (24 and 123B), cream (123D) and orange (6 and 106), with small, dark, brown spots, (223 and 223A), circular and/or elliptical, which predominated on the posterior region of the head and could join together forming larger circular spots (Figure 2). The region of snout had smaller and less frequent spots. Laterally, although in shades of gray (42 and 44) between the eye and snout, the background was lighter-colored than the back of head, matching that of the abdomen and presenting dark spots on posterior region to the eyes. Postorbital stripe was less evident. Light-colored abdomen (cream; 54), spotless. Body: body dorsal region with predominance of orange tones $(6,94$, 106 and/or 116) which had shades of cream (123D) and beige (24 and 123), with scales nearest to the ventral region in cream (54), matching the color of the abdomen. Presence of many small, dark spots in shades of brown (223 and 223A), circular and/or elliptical, which could join to form larger spots, mainly in the dorsal region. The ventral region was lighter-colored than the dorsum (cream; 54), predominantly spotless, but when present, they had the same colors and shapes as of the dorsal spots and were on the sides of the abdomen (Figure 2). Tail: The tail showed the same color as the dorsal region of body, shades of orange $(6,94,106$ and/or 116), cream $(54,123 \mathrm{D})$ and beige ( 24 and 123), and the spots were brown shaded (223 and 223A). However, these spots were present in larger quantities and could join together and reach the ventral scales. The ventral region was light-colored (cream; 54), with a few, small, dark spots in shades of brown (223A and 223B), on ventro-lateral region (Figure 2).

Distribution: Morphotype 2 had its distribution restricted to the South of Amazon River and East to Madeira River: East of Tocantins (1), Tocantins/Xingu (2), Xingu/Tapajós (1) and Tapajós/Madeira (3). Such morphotype corresponded to 5.6\% of the analyzed pattern (Table 1).

Morphotype 3 (23 specimens) - specimens in beige, brown and/or grayish-brown, with light-colored spots in relation to the background, such as watermarks, which form geometric patterns of elongated diamonds.

Description: Head: The dorsal region of the head showed the background with beige tones (123,123A and/or 239), brown $(121 \mathrm{~A}, 121 \mathrm{~B}$ and/or $121 \mathrm{C})$ and/or grayish-brown (28 and 119B) (Figure 3), with two patterns: 1) spotless or 2) back of the head with three bright spots, such as watermark, longitudinal and parallel, being two lateral and one central. At

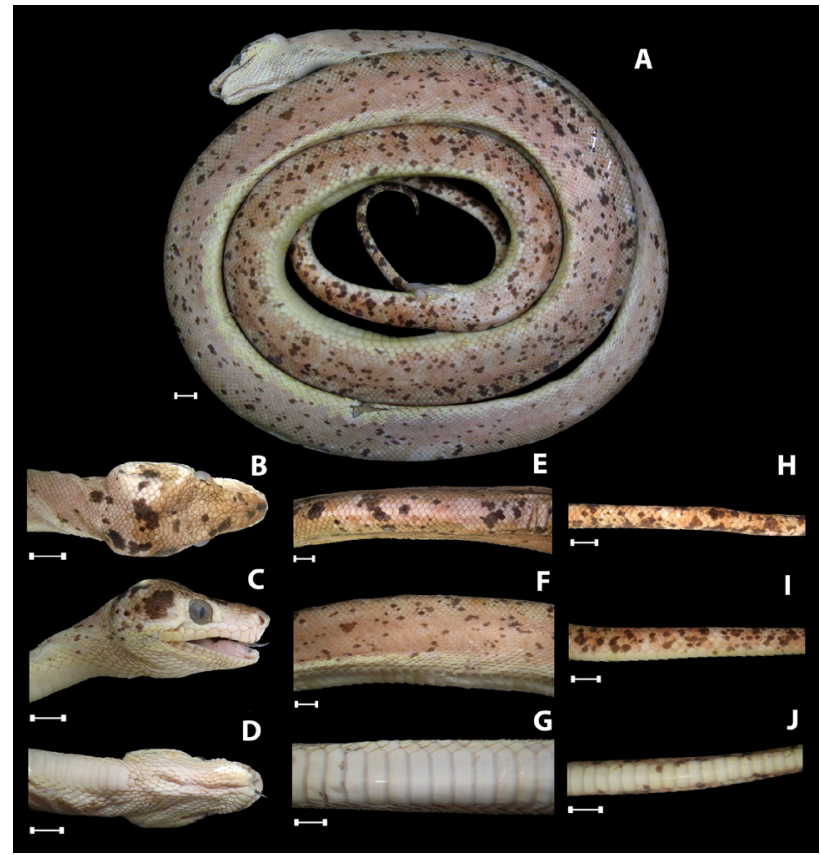

Figure 2. Morphotype 2 of Corallus hortulanus representing overview body $(\mathrm{A})$; cephalic region in dorsal $(\mathrm{B})$, lateral $(\mathrm{C})$, and ventral view $(\mathrm{C})$; median region of the body in dorsal $(E)$, lateral $(F)$, and ventral view $(G)$; dorsal $(M)$, lateral (I) and ventral view of caudal region (J). Scale bar $=10 \mathrm{~mm}$. Image colored in the electronic version.

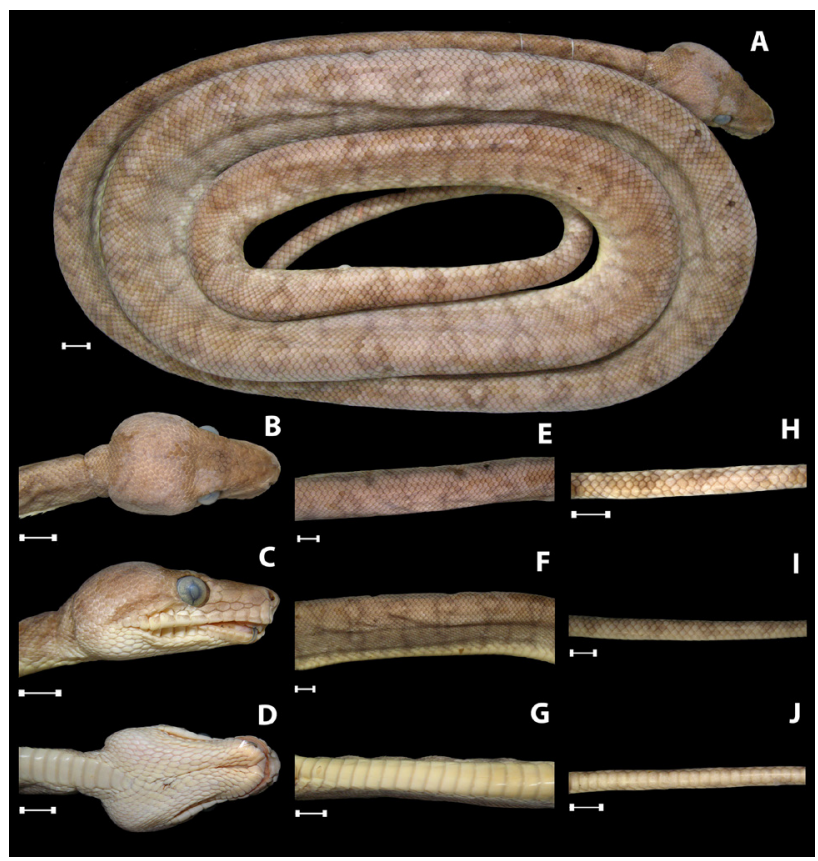

Figure 3. Morphotype 3 of Corallus hortulanus representing overview body (A); highlighting the pattern with the absence of cephalic spots in dorsal $(B)$, lateral $(C)$, and ventral view $(C)$; median region of the body in dorsal $(E)$, lateral $(F)$, and ventral view $(G)$; dorsal $(M)$, lateral $(I)$, and ventral view of caudal region (J). Scale bar $=10 \mathrm{~mm}$. Image colored in the electronic version. 
the rear end of the head, perpendicularly arranged, two small spots were found, which could be circular or linear, mingling with the background (watermark) (Figure 3). Laterally, above the supralabial scales, the head was darker, matching the color of the dorsum. The supralabial scales and, in some cases, the infraocular ones had lighter color shades of cream (54 and 92), matching the abdomen. Light postorbital stripe, not very different from background. Light-colored belly, cream (54). Body: background color of the dorsal region matched the colors of head: beige (123, 123A and/or 239), brown (121A, $121 \mathrm{~B}$ and/or 121C) and/or grayish-brown (28 and 119B), with large, empty spots, thin contour and shape of elongated diamonds. These spots were light-colored (watermark) and their lower ends extended to the abdomen. Some spots were limited to the upper half of the body or were discontinuous (Figure 3) Tail: the background color matched the body colors, beige tones (123, 123A and/or 239), brown (121A, $121 \mathrm{~B}$ and/or 121C) and/or grayish-brown (28 and 119B), but with predominance of grayish-brown shades (29). The spots on the tail were light-colored (watermark) and had the shape of small diamonds, which could be empty. The color on the back of the tail diffused into the abdomen and joined the light shades of cream (54; Figure 3).

Distribution: Morphotype 3 occurred in all south populations of the Amazon River, West of Juruá River, distributed as follows: East of Tocantins (3), Tocantins/Xingu (10), Xingu/Tapajós (1), Tapajós/Madeira (3), Madeira/Purus (1) and Purus/Juruá (1), and was also present in the north basin (4). Such morphotype represented $18.4 \%$ of the total individuals analyzed (Table 1).

Morphotype 4 (33 specimens) - specimens of brown, beige and/or cream colors. Large spots that formed geometric patterns of elongated diamonds. Its outstanding feature was the upper ends of spots, which were most evident. These ends coming from opposite sides met on the dorsum, and white spots bordered this contact region. Description: individuals with background of head in shades of beige (123A, 123B and/ or 123C) and with brown spots (121A, 121B, 223A and/or 223B; Figure 4). On the back of the head there were three parallel longitudinal dark spots, two lateral and one central spot, and at the rear end of these spots, perpendicularly arranged, were present two small dark spots which could be circular or linear. They showed two small spots on the side of the snout region, linear or rhomboid. In some individuals, these two sidebands were not restricted to the back of the head, beginning in the region of the nostrils and extending towards the posterior region, going through the supraocular scales. Laterally, there could be small circular spots on the supra and/or infralabials. Above the supralabial scales, the head was darker, matching the color of the dorsum. From supralabial towards the back of abdomen, the scales were light-colored, shades of cream (54 and 92), matching the color of the abdomen. Occurrence of dark spots of indefinite forms, near the base of the neck and next to infralabial scales. Some individuals could have spotless abdomen. Dark postorbital stripe, discontinued at times. Body: dorsum with color gradient in the vertical direction (dorsal-ventral), with darker dorsal region, greyish-brown (28) and, approaching the abdomen, it showed lighter colors, shades of beige (123A, $123 \mathrm{~B}$ and/or 123C) and cream (54 and 92; Figure 4). The spots had dark brown tones $(26,121 \mathrm{~A}, 121 \mathrm{~B}, 121 \mathrm{C}, 223 \mathrm{~A}$ and/or 223B) and/or beige (24), empty, thick contour, with lower ends that extended to the abdomen and looked like an elongated diamond. These were most evident on the extremities, especially at the dorsal end, predominantly dark tones. The upper ends of the spots on opposite sides met on dorsum and could mingle. In this meeting region, small white spots delimited the ends. The abdomen was light-colored (cream, 54) with small, circular, dark spots, shades of beige (123 and 123A) and/or brown (121B, 121C and/or 223B). Some individuals showed shades of grey (42 and 44) on the belly. Tail: the colors matched those of the body, shades of beige (123, 123A, 123B and/or 123C), with small dark spots, shades of brown (121A, 121B, 223A and/or 223B), triangular or diamond shaped which could be empty (Figure 4). The spots on opposite sides met on dorsum, mingling most of

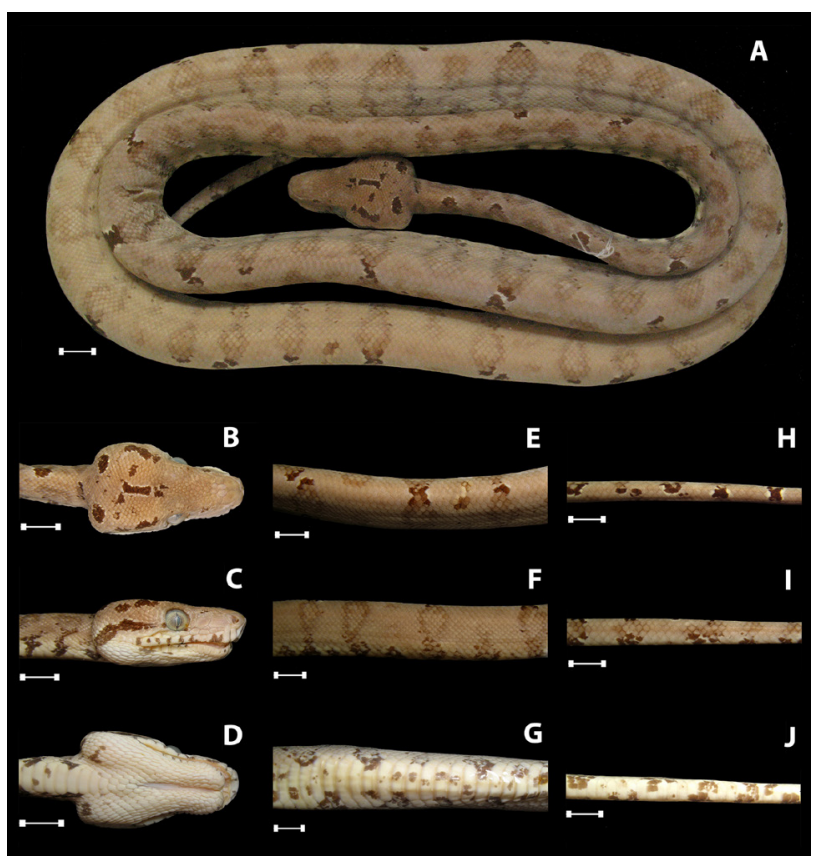

Figure 4. Morphotype 4 of Corallus hortulanus representing overview body $(A)$; cephalic region in dorsal $(B)$, lateral $(C)$, and ventral view $(C)$; median region of the body in dorsal $(E)$, lateral $(F)$, and ventral view $(G)$; dorsal $(M)$, lateral (I), and ventral view of caudal region (J). Scale bar $=10 \mathrm{~mm}$. Image colored in the electronic version. 
times. As on the body, in this meeting region, the ends were bordered by small white spots. On the abdomen, the lower ends of opposite side spots did not only occupy the sides and could be found in the central region. They also showed small, circular, dark spots, brown tones (121A, 121B, 223A and/or 223B) spread throughout the belly (Figure 4).

Distribution: Morphotype 4 was found in populations from East of Tocantins River (16), Tapajós/Madeira (5), Purus/Juruá (4) and West of Juruá River (1), and North of Amazon River (7), accounting $26.4 \%$ of the analyzed individuals (Table 1 ).

Morphotype 5 (51 specimens) - specimens of brown and/ or grayish-brown color. The background could have reticulated pattern. The spots were large and formed geometric patterns of elongated diamonds.

Description: background and spots without much distinction of colors, shades of brown (121, 121 A, 123, 221, $223,219)$, and spots delimited by thin light-colored contours, white and/or shades of cream (54 and 92; Figure 5). On the lateral region of the head there were two parallel spots in linear form, one on each side of the head, beginning in the region of the nostrils and following up to the back of the head, going through the supraocular scales. Between these two lines, there were numerous small spots, circular, elliptical and/or formless. Laterally above the supralabial scales, the head was darker, matching the color of the dorsum. From the supralabial scales, dorsum towards abdomen, the scales were light- colored, matching the color of the abdomen. The orbital stripe began in the anterior region of the eye, near the dorsum, and continued in the postorbital region. It showed small, circular spots on the snout region and on supra and infralabial scales. Light-colored abdomen, white and shades of cream (54 and 92), and small dark spots, brown tones (121A, 121B, 221A), circular and/ or elliptical, near the base of the neck and infralabials. Some still had smaller, circular spots along the groove dividing the chinshieds. Body: two patterns were shown: 1) background color similar to those of the spots, shades of beige (123 and $123 \mathrm{~A})$ and/or brown $(33,121,121 \mathrm{~A}, 121 \mathrm{~B}, 123,221,223$, 219), where the spots had predominantly darker shades or 2 ) visibly light-colored background, shades of grey (30, 42, 44, $45,84,85,119 \mathrm{C})$ when compared to the dark spots in shades of brown $(33,121,121 \mathrm{~A}, 121 \mathrm{~B}, 123,221,223,219)$. The background could have reticulated pattern: dark color scales, grayish-brown tones (28 and 119B) and/or brown $(33,121$, $121 \mathrm{~A}, 121 \mathrm{~B}, 123,221,223,219)$ interspersed with lighter color scales, shades of cream (54 and 92) and/or white. The spots were large, empty, with thick contour, and they could be discontinuous and in shape of elongated diamonds. The upper ends showed even thicker contours and their opposite sides met on dorsum and could mingle. White spots could contour this meeting region when present. The lower ends extended to the abdomen. Interpolating the larger spots, the design pattern showed the presence of spots with secondary forms of vertical stripes that could extend up to the dorsum and the majority was discontinuous. The abdomen was light-colored, cream (54 and 92) and/or white and the majority presented a large quantity of tiny, circular, dark spots in shades of brown $(33,121,121 \mathrm{~A}, 121 \mathrm{~B}, 123,221,223,219)$, or light-colored in shades of beige (123 and 123A) spread throughout the abdomen (cream; 54 and 92). Tail: background with the same colors as of the body, predominantly darker shades (Figure 5). Individuals that had reticulated pattern on the body did not display it on the tail. The spots also had the same color as those of the body, predominantly darker shades, and with circular and/or elliptical shape. The upper ends of the spots presented the same pattern found on the body. Abdomen background colors followed the same pattern as of the body with the presence of dark spots in the same colors as dorsum, which predominated over the background.

Distribution: Morphotype 5 was observed in populations from East of Tocantins (6), Tocantins/Xingu (18), Xingu/ Tapajós (4), Tapajós/Madeira (11), Madeira/Purus (6), Purus/ Juruá (3) and West of Juruá River (2), and the north basin (1). Morphotype 5 presented more frequently among the analyzed sample (40.8\%; Table 1$)$.

Morphotype 6 (two specimens) - specimens in lighter color, spotless or designless, with the exception of the tail

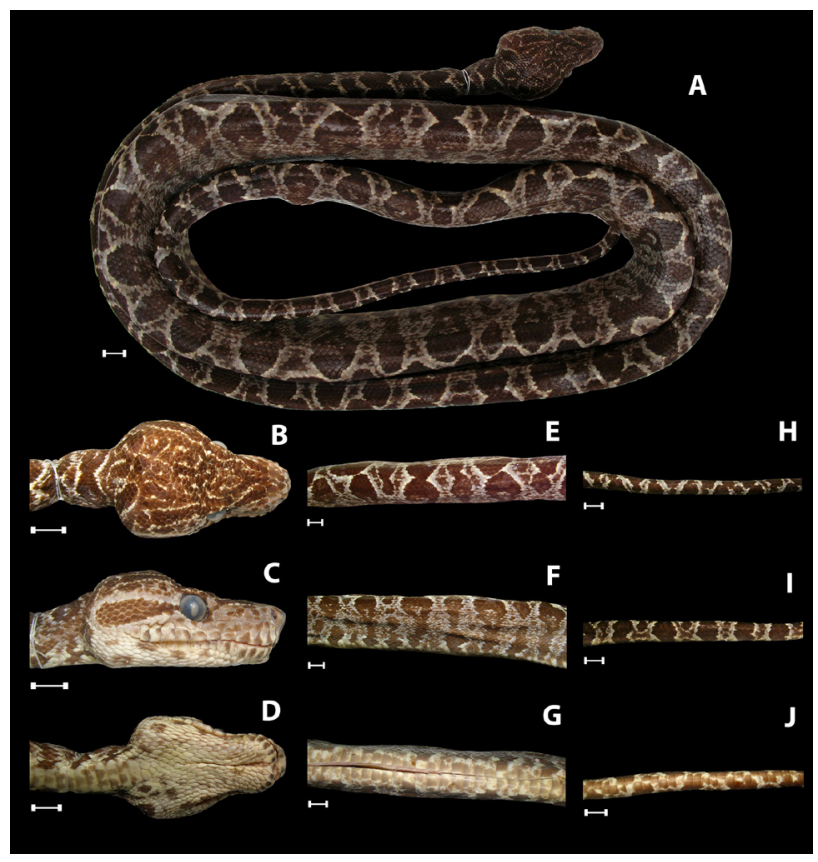

Figure 5. Morphotype 5 of Corallus hortulanus representing overview body (A); cephalic region in dorsal $(B)$, lateral $(C)$, and ventral view $(C)$; median region of the body in dorsal $(E)$, lateral $(F)$, and ventral view $(G)$; dorsal $(M)$, lateral $(\mathrm{I})$, and ventral view of caudal region $(\mathrm{J})$. Scale bar $=10 \mathrm{~mm}$. Image colored in the electronic version. 
which showed a few dark spots in relation to the background. Head, body and tail had the same homogeneous color pattern on dorsum and abdomen, head, body and tail. Dorsally, they were light-colored, shades of white, cream $(54,56,92$, 121D, 123D and/or 124; Figure 6) and with white and cream abdomen, predominantly the lighter shades. It did not present dorsal or ventral spots, with exception of the tail which showed a few dark spots in relation to background: shades of beige (123A) and/or brown (223A, 223B, 223C), sparse and small on the dorsum and abdomen, circular, scattered and small on the dorsum and abdomen.

Distribution: Only two specimens were recorded, one was from the interfluve Tocantins/Xingu and the other from Madeira/Purus. This morphotype represented only $1.6 \%$ of the individuals analyzed (Table 1).

\section{Geographical distribution}

After the classification and identification of the morphotypes, it was observed that morphotype 2 is restricted to the south of the Amazon River to the East of Madeira River, while the morphotype 6 is also restricted to the East of Purus River. Morphotypes 5 and 3 presented wide distribution, but contrary to morphotype 5 , morphotype 3 was the less frequent in the populations analyzed (Figure 7).

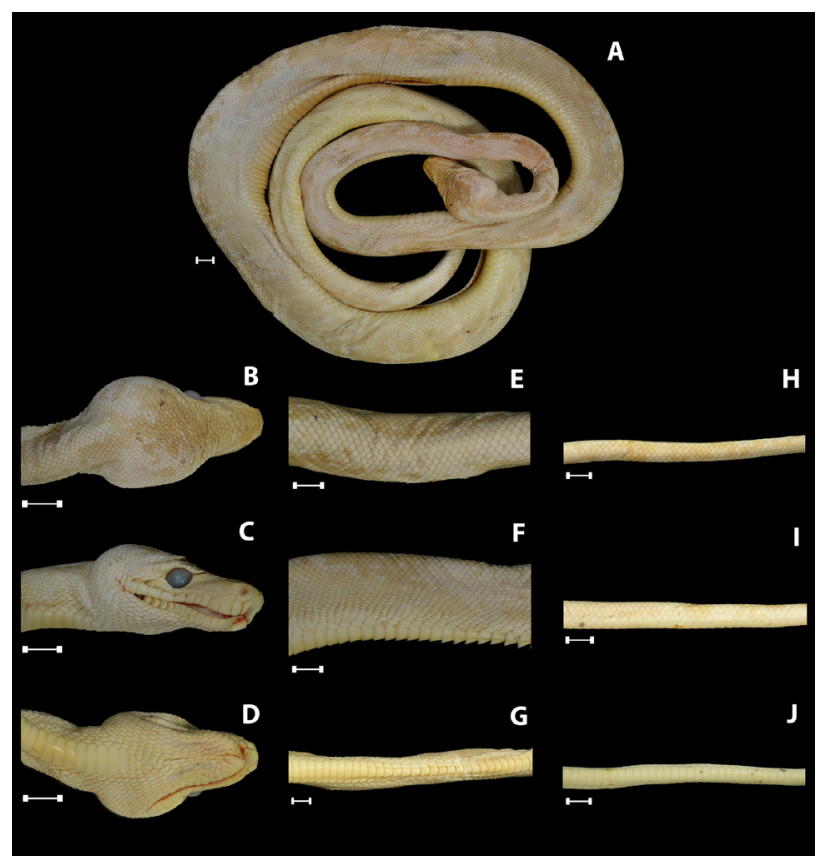

Figure 6. Morphotype 6 of Corallus hortulanus representing overview body $(A)$; cephalic region in dorsal $(B)$, lateral $(C)$, and ventral view (C); median region of the body in dorsal $(E)$, lateral $(F)$, and ventral view $(G)$; dorsal $(M)$, lateral (I), and ventral view of caudal region (J). Scale bar $=10 \mathrm{~mm}$. Image colored in the electronic version.
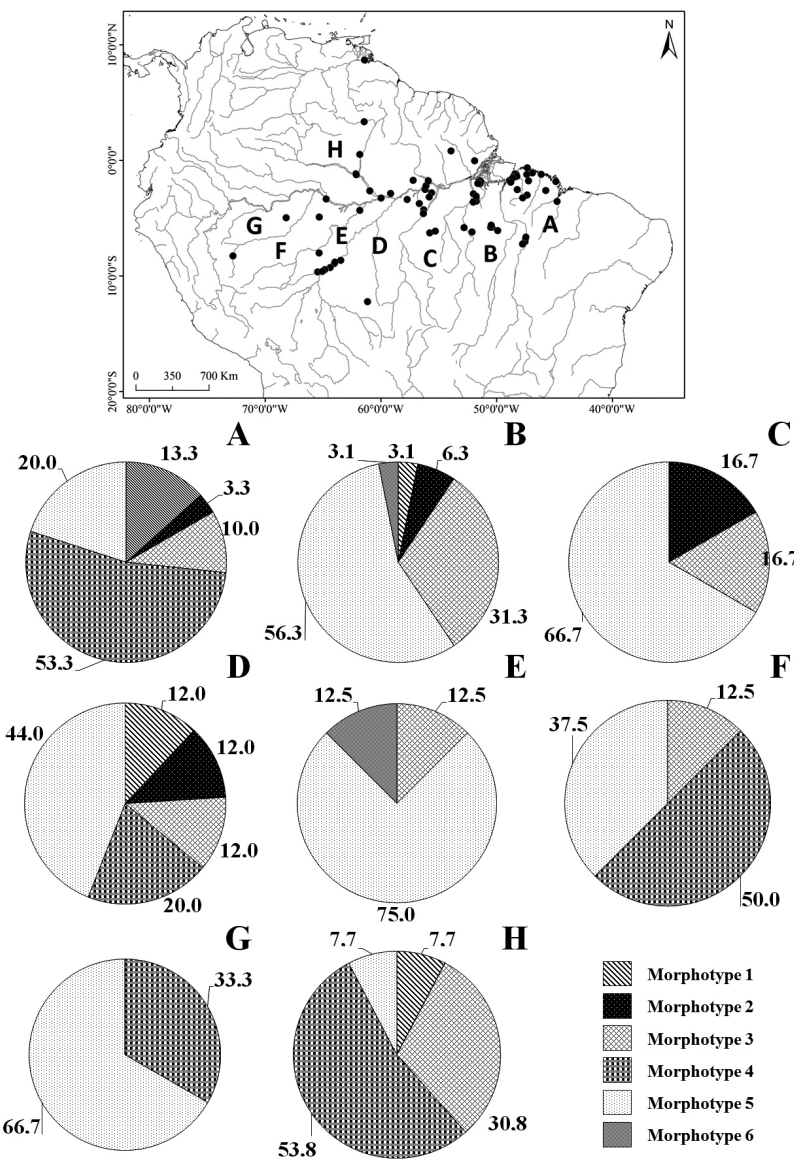

Figure 7. Distribution map of Corallus hortulanus analyzed in the North and South Basin of the Amazon River, Brazil. Representation of the proportions of morphotypes by South and North interfluves of Amazon River: A) East of Tocantins; B) Interfluve Tocantins/Xingu; C) Interfluve Xingu/Tapajós; D) Interfluve Tapajós/Madeira; E) Interfluve Madeira/Purus; F) Interfluve Purus/ Juruá; G) West Jurua; and H) North Basin.

In the North of Amazon River, morphotypes 1 (7.69\% of total) and $5(15.38 \%$ of total) were the least frequent, while morphotype 4 is most frequent $(53.85 \%$; Figure 7$)$. Morphotypes 1, 3, 4 and 5 were present in the Amazon (South and North), and also in the populations of the Cerrado, Caating and Atlantic forest, in Brazil.

\section{Sex ratio of morphotypes}

Morphotypes 2 and 3 had a sex ratio other than 1:1; morphotype 2 exhibited $16.7 \%$ of females and $83.3 \%$ of males ( $\mathrm{p}<0.001)$ and morphotype 3 showed $34.8 \%$ of females and $65.2 \%$ of males $(\mathrm{p}=0.029)$ (Table 2$)$. The analysis was not performed for morphotype 6 due to low number of available specimens. In addition, three specimens were removed from the analysis because they could not have their gender identified. Thus, 120 individuals were considered for the sex ratio analysis. 
Table 2. Sexual proportion of Corallus hortulanus for the described morphotypes (M). Absent numbers are indicated with (-).

\begin{tabular}{|c|c|c|c|c|c|c|c|c|c|c|c|c|}
\hline \multirow{2}{*}{ Sex } & \multicolumn{2}{|c|}{ M1 } & \multicolumn{2}{|c|}{ M2 } & \multicolumn{2}{|c|}{ M3 } & \multicolumn{2}{|c|}{ M4 } & \multicolumn{2}{|c|}{ M5 } & \multicolumn{2}{|c|}{ M6 } \\
\hline & $\mathrm{N}$ & $\%$ & $\mathrm{~N}$ & $\%$ & $\mathrm{~N}$ & $\%$ & $\mathrm{~N}$ & $\%$ & $\mathrm{~N}$ & $\%$ & $\mathrm{~N}$ & $\%$ \\
\hline Female & 5 & 55.6 & 1 & 16.7 & 8 & 34.8 & 13 & 40.6 & 27 & 54.0 & 2 & 100.0 \\
\hline Male & 4 & 44.4 & 5 & 83.3 & 15 & 65.2 & 19 & 59.4 & 23 & 46.0 & 0 & - \\
\hline$X^{2}$ & \multicolumn{2}{|c|}{0.629} & \multicolumn{2}{|c|}{25.016} & \multicolumn{2}{|c|}{4.739} & \multicolumn{2}{|c|}{1.784} & \multicolumn{2}{|c|}{0.321} & \multicolumn{2}{|c|}{-} \\
\hline value-p & \multicolumn{2}{|c|}{0.428} & \multicolumn{2}{|c|}{$<0.001$} & \multicolumn{2}{|c|}{0.029} & \multicolumn{2}{|c|}{0.182} & \multicolumn{2}{|c|}{0.571} & \multicolumn{2}{|c|}{ - } \\
\hline
\end{tabular}

\section{DISCUSSION}

The analysis of the chromatic variation of $C$. hortulanus populations present in the South basin of the Amazon River allow for the description of six morphotypes, confirming the polymorphic condition of the species as mentioned by Henderson et al. (1995; 1997). The grayish-brown color (morphotypes 3 and 5), and diamond-shaped spots pattern (on all morphotypes, except morphotype 2) are the most common conditions among the populations studied, agreeing with the results of Henderson (1997).

Recently, the polymorphism in snakes has been correlated to the resilience of species, with the polymorphic ones being significantly older than those monomorphic, although there have been records of old monomorphic species and recent polymorphic ones (Pizzato and Dubey 2012). In C. hortulanus this condition seems not to apply because the species would have appeared recently, according to Colston et al. (2013), in South America during the Middle Miocene ( $\sim 11.9$ million years).

In the search for evidence regarding the exploration of resources in polymorphic populations, Cain and Sheppard (1954) concluded that the polymorphism would influence on the distribution as well as a wide distribution would favor the polymorphic condition. The chromatic variation of $C$. hortulanus can be associated with two other factors in addition to its wide distribution which point to a phenotypic response to local environmental conditions: foraging "sit and wait" strategy used by adults that rely on cryptic coloration to avoid detection by predators and prey; and low vagility of species (Henderson 1997).

Regardless of the relationship between polymorphism and geographic distribution, most studies agree that the polymorphic condition directly influences the ecological success of a species. According to Forsman et al. (2008), the coexistence of at least two color patterns may promote greater ecological success of populations and species. Lizards, snakes and polymorphic anuran from Australia, and with wide distribution, use ample diversity of habitats and are less frequent among species listed as threatened (Forsman and Berg 2008; Forsman and Hagman 2009). Probably the large chromatic variation of $C$. hortulanus is directly linked to its ecological success in different habitats, as well as its presence in different biomes (Cunha and Nascimento 1993; Henderson et al. 1995; Henderson 1997).

Henderson (1997) suggested that the polymorphism of $C$. hortulanus can also be associated with gene flow rate among its populations and that this rate may be stopped naturally (as by rivers) or by human action (such as agricultural practice). The results indicate that the described morphotypes for $C$. hortulanus do not show correlation with the geographic distribution, suggesting gene flow among populations present in the interfluves analyzed. This hypothesis can be corroborated by the presence of some morphotypes on both banks of the Amazon River, indicating that this river and its main tributaries do not act as a barriers to $C$. hortulanus. The morphotypes described in the Amazonian populations are also recorded in Mata Atlântica and Caatinga, indicating a broad distribution of chromatic patterns of $C$. hortulanus.

Despite the absence of correlation between most of the chromatic patterns of $C$. hortulanus and the interfluves, it is possible to observe a restricted distribution trend of morphotype 2 (to the east of Madeira River) and morphotype 6 (to the east of Jurua River). The distribution pattern where the rivers act as barriers to dispersal is reported for various groups of animals, including snakes (Silva and Sites 1995; Avila-Pires et al. 2009). The results of this work suggest two hypotheses, nonexcludable, to explain the polymorphism of $C$. hortulanus: 1 ) there is gene flow among populations, regardless of geographical distance and natural barriers; and 2) the color and design patterns are probably a phenotypic response to pressure in different environments occupied by the species.

\section{CONCLUSION}

The polychromatism featured in populations of $C$. hortulanus (Squamata: Boidae) in south of the Amazon Basin in Brazil can be described in six morphotypes. Although morphotypes 2 and 6 have restricted distribution, no correlation between the interfluves and chromatic patterns is observed. The lack of geographical isolation of the morphotypes suggests a possible gene flow among populations of the interfluves and among those of the biomes indicating that the rivers and large geographic distances do not act as barriers to $C$. hortulanus. 


\section{ACKNOWLEDGEMENTS}

The authors thank Coordenação de Aperfeiçoamento de Pessoal de Nível Superior (CAPES) for granting Master's Scholarship (MOD); Conselho Nacional de Desenvolvimento Científico e Tecnológico (CNPq) for the research support (ALCP - Grant number 565046/2010-1 and 305475/20142); Dr. Felipe G. Grazziotin for the valuable suggestions; collection curators for lending the material; Leonardo Marques for English review; Museu Paraense Emílio Goeldi and Curso de Pós-graduação em Zoologia MPEG/UFPA for the facilities and opportunities to conduct the research.

\section{REFERENCES}

Ávila-Pires, T.C.S.; Vitt, L.J.; Sartorius, S.S; Zani, P.A. 2009. Squamata (Reptilia) from four sites in southern Amazonia, with a biogeographic analysis of Amazonian lizards. Boletim Museu Paraense Emílio Goeldi, 4: 99-118.

Cain, A.J.; Sheppard, P.M. 1954. The theory of adaptive polymorphism. The American Naturalist, 88: 321-326.

Colston T.J.; Grazziotin, F.G.; Shepard, D.B.; Vitt, L.J.; Colli, G.R.; Henderson, R.W. 2013. Molecular systematics and historical biogeography of tree boas (Corallus spp.). Molecular Phylogenetics and Evolution, 66: 953-959.

Cunha, O.R.; Nascimento, F.P. 1993. Ofídios da Amazônia: as cobras da região leste do Pará. Boletim do Museu Paraense Emílio Goeldi, 9: 1-191.

Farallo, V.R.; Forstner, M.R.J. 2012. Predation and the maintenance of color polymorphism in a habitat specialist Squamate. PLoS ONE, 7: e30316.

Forsman, A.; Ahnesjo, J.; Caesar, S.; Karlsson, M. 2008. A model of ecological and evolutionary consequences of color polymorphism. Ecology, 89: 34-40.

Forsman, A.; Berg, V.A. 2008. Associations of variable coloration with niche breadth and conservation status among Australian reptiles. Ecology, 89: 1201-1207.

Forsman, A.; Hagman, M. 2009. Association of coloration mode with population declines and endangerment in Australian frogs. Conservation Biology, 23: 1535-1543.
Freitas, M.A. 2003. Serpentes Brasileiras. Lauro de Freitas, Salvador, 160p.

Hammer, O.; Harper, D.A.T.; Rian, P.D. 2001. Past: Palaeonthological statistics software package for education and data analysis. Versão 1.37 (http://palaeo-electronica.org/2001_1/past/issue1_01. htm). Acesso em 19/11/2013.

Henderson, R.W. 1997. A taxonomic review of the Corallus hortulanus complex of Neotropical tree boas. Caribbean Journal of Science, 4: 198-221.

Henderson, T.; Waller, P.; Micucci, G.; Bourgeois, R.W. 1995. Ecological correlates and patterns in the distribution of Neotropical boines (Serpentes: Boidae): a preliminary assessment. Herpetology Natural History, 3: 15-27.

Noonan, B.P.; Chippindale, P.T. 2006. Dispersal and vicariance: the complex evolutionary history of boid snakes. Molecular Phylogenetics and Evolution, 40: 347-358.

Pizzatto, L.; Dubey, S. 2012. Colour-polymorphic snake species are older. Biological Journal of the Linnean Society, 107: 210-218.

Pizzatto, L.; Marques, O.A.V. 2007. Reproductive ecology of boine snakes with emphasis on Brazilian species and a comparison to pythons. South American Journal of Herpetology, 2: 107-122.

Rodrigues, M.T. 1996. Lizards, snakes and amphisbaenians from the quaternary sand dunes of the middle Rio São Francisco, Bahia, Bazil. Journal of Herpetology, 30: 513-523.

Silva, N.J.; Sites, J.W. 1995. Patterns of diversity of Neotripical squamate reptile species with emphasis on the Brazilian Amazon and the conservation potential of indigenous reserves. Conservation Biology, 9: 873-901.

Smith, F.B. 1975. Naturalist's Color Guide. Parts I and II. American Museum of Natural History, New York, 16p.

Terribile, L.C.; Olalla-Tárraga, M.A.; Morales-Castilla, I.; Rueda, M.; Vidanes, R.M.; Rodríguez, M.A.; Diniz-Filho, J.A.F. 2009. Global richness patterns of venomous snakes reveal contrasting influences of ecology and history in two different clades. Oecologia, 159: 617-626.

Recebido em 24/02/2015

Aceito em 11/05/2015 
